\title{
Radical Intermediates in the Catalytic Oxidation of Hydrocarbons by Bacterial and Human Cytochrome P450 Enzymes ${ }^{\dagger}$
}

\author{
Yongying Jiang, Xiang He, and Paul R. Ortiz de Montellano* \\ Department of Pharmaceutical Chemistry, University of California, $60016^{\text {th }}$ Street, San Francisco, \\ California 94143-2280
}

\section{Abstract}

Cytochromes $\mathrm{P} 450_{\text {cam }}$ and $\mathrm{P} 450_{\mathrm{BM} 3}$ oxidize $\alpha$ - and $\beta$-thujone into multiple products, including 7 hydroxy- $\alpha$-(or $\beta$-)thujone, 7,8-dehydro- $\alpha$-(or $\beta$-)thujone, 4-hydroxy- $\alpha$-(or $\beta$-)thujone, 2-hydroxy $\alpha$ (or $\beta$-)thujone, 5-hydroxy-5-isopropyl-2-methyl-2-cyclohexen-1-one, 4,10-dehydrothujone, and carvacrol. Quantitative analysis of the 4-hydroxylated isomers and the ring opened product indicates that the hydroxylation proceeds via a radical mechanism with a radical recombination rate ranging from $0.7 \pm 0.3 \times 10^{10} \mathrm{~s}^{-1}$ to $12.5 \pm 3 \times 10^{10} \mathrm{~s}^{-1}$ for trapping of the carbon radical by the iron-bound hydroxyl radical equivalent. 7-[ $\left.{ }^{2} \mathrm{H}\right]-\alpha-$ Thujone has been synthesized and used to amplify $\mathrm{C}-4$ hydroxylation in situations where uninformative $\mathrm{C}-7$ hydroxylation is the dominant reaction. The involvement of a carbon radical intermediate is confirmed by the observation of inversion of stereochemistry of the methyl-substituted C-4 carbon during the hydroxylation. With an L244A mutation that slightly increases the $\mathrm{P} 450_{\text {cam }}$ active site volume, this inversion is observed in up to $40 \%$ of the C-4 hydroxylated products. The oxidation of $\alpha$-thujone by human CYP1A2, CYP2C9, CYP2C19, CYP2D6, CYP2E1, and CYP3A4 occurs with up to 80\% C-4 methyl inversion, in agreement with a dominant radical hydroxylation mechanism. Three minor desaturation products are produced, at least one of them via a cationic pathway. The cation involved is proposed to form by electron abstraction from a radical intermediate. The absence of a solvent deuterium isotope effect on product distribution in the $\mathrm{P} 450_{\text {cam }}$ reaction precludes a significant role for the $\mathrm{P} 450$ ferric hydroperoxide intermediate in substrate hydroxylation. The results indicate that carbon hydroxylation is catalyzed exclusively by a P450 ferryl species via radical intermediates whose detailed properties are substrate- and enzyme-dependent.

\begin{abstract}
The regio- and stereoselective hydroxylation of hydrocarbons by cytochrome P450 enzymes is a chemically demanding but physiologically important reaction. Hydroxylation is required, for example, for the conversion of cholesterol into a panoply of mammalian sterol hormones and of arachidonic acid into vasodilator and vasoconstrictor signaling molecules $(1,2)$. The mechanism of carbon hydroxylation has been thought for three decades to involve hydrogen abstraction by the catalytic ferryl species followed by recombination of the resulting substrate carbon radical with the equivalent of an iron-bound hydroxyl radical $(3,4)$. The ferryl species involved in this reaction is generated by reductive activation of molecular oxygen at the iron

\footnotetext{
${ }^{\dagger}$ This work was supported by grant GM25515 from the National Institutes of Health.

* To whom editorial correspondence should be addressed: Dr. Paul Ortiz de Montellano University of California Genentech Hall GHN572D $60016^{\text {th }}$ Street San Francisco, CA 94143-2280 TEL: (415) 476-2903 FAX: (415) 502-4728 e-mail: ortiz@ cgl.ucsf.edu

SUPPORTING INFORMATION AVAILABLE. Tables S1, S2, and S3, Figure S1-S9 show GC-MS of thujone metabolite standards, ${ }^{1} \mathrm{H}$ NMR and GC-MS of $7\left[{ }^{2} \mathrm{H}\right]-\alpha$-thujone, identification of metabolites formed in the reaction of $\mathrm{P} 450_{\text {cam }}$ with $\alpha$-thujone, identification of carvacrol and ROP formed in the reaction of $\mathrm{P} 450$ cam with $7\left[{ }^{2} \mathrm{H}\right]-\alpha$-thujone, ion chromatogram region of $4 \mathrm{OH} \alpha \mathrm{T}$, $2 \mathrm{OH} \alpha \mathrm{T}$, and $4 \mathrm{OH} \beta \mathrm{T}$ formed in the reaction of $\mathrm{P} 450_{\mathrm{cam}} \mathrm{L} 244 \mathrm{~A}$ mutant with $\alpha$-thujone, identification of metabolites formed in the reaction of CYP3A4 with $\alpha$-thujone, ion chromatogram region of $4 \mathrm{OH} \alpha \mathrm{T}$ and $4 \mathrm{OH} \beta \mathrm{T}$ in the reactions of $\alpha \mathrm{T}$ with $\mathrm{CYP} 1 \mathrm{~A} 2,-2 \mathrm{C} 9,-2 \mathrm{C} 19,-2 \mathrm{D} 6$, and $-2 \mathrm{E} 1$.
} 
center of the prosthetic heme group (5). Although the distribution of electrons in this catalytic ferryl species remains experimentally ambiguous, it is generally formulated as a peroxidase Compound I-like intermediate, with the heme iron in the Fe(IV) state and the second oxidation equivalent stored either as a porphyrin or protein radical (6). The radical rebound mechanism described above is supported by a variety of data, including the large magnitude of the intramolecular isotope effect when the abstracted hydrogen is replaced by a deuterium $(3,4$, 7 ), the observation of allylic and skeletal rearrangements during hydroxylation reactions (8-10), and density function computational analyses (6). However, one line of evidence, determination of the carbon radical lifetime by radical clock substrates, has given conflicting results. The first such study employing bicyclo[2.1.0]pentane as the probe suggested a rate of $1.4 \times 10^{10} \mathrm{~s}^{-1}$ for the rate of recombination of the carbon radical and iron bound hydroxyl radical $(11,12)$. A rate of this order has also been supported in recent studies of radical clocks based on norcarane, thujone, and cyclopropyl fatty acids (13-16). However, studies of a series of clocks calibrated to rearrange at faster and faster rates did not give the expected increases in the proportion of rearranged to unrearranged products (17-20). This perceived shortcoming in the radical recombination mechanism $(17,20)$, and studies with probes that discriminate between radical and cationic intermediates, led to the proposal that the ferric hydroperoxide precursor of the ferryl species might itself insert into the $\mathrm{C}-\mathrm{H}$ bond, yielding a cationic rather than radical intermediate (21-23).

In order to address these conflicting findings, we recently introduced and developed $\alpha$ - and $\beta$ thujone as novel two-zone radical clocks $(14,24)$. These clocks not only have a classical cyclopropyl substituent attached to the reacting carbon but also a methyl-substituted carbon that can undergo inversion. Thus, the nature of the carbon intermediate formed in the reaction can be probed simultaneously by the extent of cyclopropyl ring opening and C-4 inversion. Furthermore, a cationic rather than radical intermediate gives distinguishable products. In the earlier studies, the oxidation of $\alpha$ - and $\beta$-thujone by P450 cam (CYP101) and $\mathrm{P} 450_{\mathrm{BM} 3}$ (CYP102) was investigated using gas chromatography with flame ionization detection to quantitate the reaction products (14). The results of those studies fully supported the operation of a radical rebound mechanism. We have now refined the assay methodology by shifting to a GC-MS detection system and employing a wider array of synthetic standards. The results have enabled both a more precise determination of the rebound rate for the $\mathrm{P} 450_{\text {cam }}$ and $\mathrm{P}_{450} \mathrm{BM}_{3}$-dependent oxidations as well as detection of carvacrol and the 4,10-desaturated product, both of which derive from a cationic intermediate. In a further exploration of the influence of the active site on the radical rebound process, we have (a) examined the oxidation of $\alpha$-thujone by the $\mathrm{P} 450_{\text {cam }}$ L244A mutant, which has a slightly larger active site, (b) determined the product profiles in the reactions catalyzed by six human P450 enzymes with relatively large active sites, (c) analyzed the effect on the $\mathrm{P} 450_{\text {cam }}$ reaction of changing the $\mathrm{pH}$ of the medium, and (d) carried out the reaction in highly deuterated medium to test for involvement of the Fe-OOH intermediate as a hydroxylating species. The results confirm the predominant radical nature of the catalytic processes involved in hydrocarbon hydroxylation and argue against a direct hydroxylating role for the $\mathrm{Fe}-\mathrm{OOH}$ intermediate.

\section{EXPERIMENTAL SECTION}

\section{General Materials}

Six recombinant human P450 enzymes, CYP1A2, -2C9, -2C19, -2D6, -2E1, and -3A4 together with recombinant cytochrome $\mathrm{P} 450$ reductase were purchased from Biocatalytics Inc. (Pasadena, CA). $\alpha$-Thujone $(\geq 96 \%)$ and all the other reagents, unless otherwise mentioned, were from Sigma-Aldrich. The only impurity found in $\alpha$-thujone was $\beta$-thujone $(\leq 4 \%)$, which can be removed to $\leq 1 \%$ by flash column chromatography on silica gel (hexanes $/ \mathrm{CH}_{2} \mathrm{Cl}_{2}$, $30 / 1-10 / 1)$. Both commercial $\alpha$-thujone ( $\geq 96 \%)$ and the purified $\alpha$-thujone $(\geq 99 \%)$ were used 
for enzyme assays. $\beta$-Thujone was purified to $\geq 99 \%$ ( $\alpha$-thujone $\leq 1 \%$ ) by flash column chromatography on silica gel (hexanes $/ \mathrm{CH}_{2} \mathrm{Cl}_{2}, 30 / 1-10 / 1$ ). Yeast extract, tryptone, $2 \mathrm{YT}$ medium, sodium chloride, EDTA, and organic solvents were obtained from Fisher Scientific (Fair Lawn, NJ). Isopropyl- $\beta$-d-thiogalactopyranoside was from FisherBiotech (Fair Lawn, $\mathrm{NJ}$ ), and ampicillin from Promega (Madison, WI). All of the chemicals were used without purification unless otherwise indicated. Solid-phase extraction of metabolites was carried out with Bond-Elut cartridges C18 (200 mg, $3 \mathrm{~mL}$ ) (Varian). Cartridges were conditioned sequentially with $2 \mathrm{~mL}$ each of methanol, ethyl acetate, and water. The samples were then transferred to the cartridges and slowly drawn through. Cartridges were then washed with 2 $\mathrm{mL}$ of water and thoroughly dried for $1 \mathrm{~h}$ with nitrogen at $15 \mathrm{psi}$. The metabolites were eluted using two 1-mL aliquots of ethyl acetate.

\section{GC-MS Analyses of Thujones and their Metabolites}

Analyses were performed on an Agilent 6850 gas chromatograph coupled to an Agilent 5973 Network Mass Selective Detector in the flame ionization mode. Helium was used as the carrier gas. The GC was equipped with an HP-5MS cross-linked 5\% PH ME Siloxane capillary column (30 m, $0.25 \mathrm{~mm}$ i.d., $0.25 \mu \mathrm{m}$ film thickness). The temperature program was $70{ }^{\circ} \mathrm{C}$ for $1 \mathrm{~min}$ and then $70-280{ }^{\circ} \mathrm{C}$ at $15^{\circ} \mathrm{C} / \mathrm{min}$ or $70{ }^{\circ} \mathrm{C}$ for $5 \mathrm{~min}, 70-160^{\circ} \mathrm{C}$ at $5^{\circ} \mathrm{C} / \mathrm{min}$, and then $160-280$ ${ }^{\circ} \mathrm{C}$ at $20^{\circ} \mathrm{C} / \mathrm{min}$. The temperatures were $250{ }^{\circ} \mathrm{C}$ for the injection port and $280{ }^{\circ} \mathrm{C}$ for the detector. A sample of $3 \mu \mathrm{L}$ was injected in a 10:1 split ratio onto the column. Identification of the thujones and their metabolites involved comparison with authentic standards by cochromatography and mass spectrometric fragmentation patterns both as the parent compounds and, where appropriate, as the trimethylsilyl (TMS) derivatives. Product yields were determined by digital integration of the total GC ion current using the resident HP ChemStation software.

\section{Synthesis}

$\beta$-Thujone $(\beta \mathrm{T})^{1}(25), 4,10$-dehydrothujone (410DHT), 4-hydroxy- $\alpha$-thujone (4OH $\left.\alpha \mathrm{T}\right), 4$ hydroxy- $\beta$-thujone (4OH $\beta \mathrm{T}),(2 R)$-2-hydroxy- $\alpha$-thujone (2OH $\alpha \mathrm{T}), 7$-hydroxy- $\alpha$-thujone

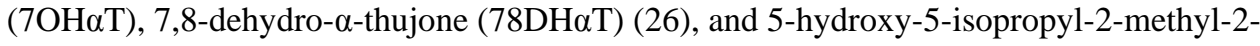
cyclohexen-1-one (ROP) (27) were prepared according to the indicated published procedures. The purity of all products was assessed by ${ }^{1} \mathrm{H}$ NMR and GC-MS.

\section{Preparation of $7-\left[{ }^{2} \mathrm{H}\right]-\alpha-$ Thujone}

To a stirred solution of 7-hydroxy- $\alpha$-thujone $(23 \mathrm{mg}, 0.14 \mathrm{mmol})$ and $\mathrm{Et}_{3} \mathrm{SiD}(100 \mu \mathrm{L})$ in dry $\mathrm{CH}_{2} \mathrm{Cl}_{2}(6 \mathrm{~mL})$ at $-10{ }^{\circ} \mathrm{C}$ was added a solution of $\mathrm{BF}_{3}$ etherate $(48 \%, 100 \mu \mathrm{L})$. The reaction was continued with stirring at $-5^{\circ} \mathrm{C}$ for $1 \mathrm{~h}$ and was then quenched by adding saturated $\mathrm{Na}_{2} \mathrm{CO}_{3}(1 \mathrm{~mL})$. The $\mathrm{CH}_{2} \mathrm{Cl}_{2}$ phase was separated and dried over anhydrous $\mathrm{Na}_{2} \mathrm{SO}_{4}$, filtered and concentrated on a rotary evaporator. The residue was chromatographed on silica gel (hexanes $/ \mathrm{CH}_{2} \mathrm{Cl}_{2}, 30 / 1-10 / 1$ ) to give the desired compound as a colorless oil (GC-MS purity 99.0\%): ${ }^{1} \mathrm{H} \mathrm{NMR}\left(\mathrm{CDCl}_{3}, 400 \mathrm{MHz}\right) \delta \mathrm{ppm} 2.56(\mathrm{~d}, \mathrm{~J}=18.8 \mathrm{~Hz}, 1 \mathrm{H}), 2.23(\mathrm{q}, \mathrm{J}=7.5 \mathrm{~Hz}$, $1 \mathrm{H}), 2.08(\mathrm{~d}, \mathrm{~J}=19.2 \mathrm{~Hz}, 1 \mathrm{H}), 1.17(\mathrm{~d}, \mathrm{~J}=7.6 \mathrm{~Hz}, 3 \mathrm{H}), 1.09(\mathrm{dd}, \mathrm{J}=8,4 \mathrm{~Hz}, 1 \mathrm{H}), 1.01(\mathrm{~s}$, $3 \mathrm{H}), 0.96(\mathrm{~s}, 3 \mathrm{H}), 0.77(\mathrm{t}, \mathrm{J}=6 \mathrm{~Hz}, 1 \mathrm{H}), 0.13(\mathrm{t}, \mathrm{J}=5 \mathrm{~Hz}, 1 \mathrm{H})$; GC-MS (FID) $153\left(\mathrm{M}^{+}\right), 138$, $125,111,96,81,68$.

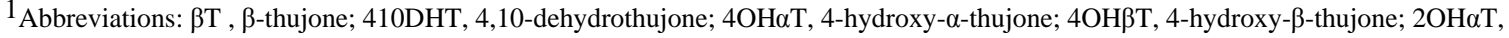
(2R)-2-hydroxy- $\alpha$-thujone; 7OH $\alpha \mathrm{T}$, 7-hydroxy- $\alpha$-thujone; $78 \mathrm{DH} \alpha \mathrm{T}, 7,8$-dehydro- $\alpha$-thujone; ROP, 5 -hydroxy-5-isopropyl-2-methyl-2cyclohexen-1-one; carv, carvacrol.
} 


\section{Preparation of Enzymes}

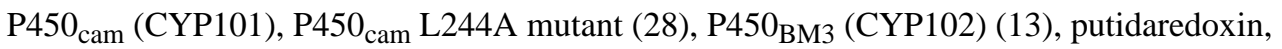
and putidaredoxin reductase (28) were expressed heterologously in Escherichia coli and were purified as previously reported (28). The purified $\mathrm{P} 450_{\text {cam }}$ or P450 $0_{\text {cam }} \mathrm{L} 244 \mathrm{~A}$ mutant containing camphor was flash frozen over dry ice and stored at $-70{ }^{\circ} \mathrm{C}$. The camphor present in the protein sample was removed prior to use by two passages through a PD-10 size exclusion column eluted with $100 \mathrm{mM}$ potassium phosphate buffer at $\mathrm{pH} 7.4\left(37^{\circ} \mathrm{C}\right)$.

\section{Enzyme Incubations}

Unless otherwise indicated, the buffer was $100 \mathrm{mM}$ potassium phosphate at $\mathrm{pH} 7.4\left(37^{\circ} \mathrm{C}\right)$. In the case of $\mathrm{P} 450_{\text {cam }}$ and the $\mathrm{P} 450_{\text {cam }} \mathrm{L} 244 \mathrm{~A}$ mutant, the enzyme $(2 \mu \mathrm{M})$, putidaredoxin $(10$ $\mu \mathrm{M})$, putidaredoxin reductase $(2 \mu \mathrm{M})$, substrate $(1 \mathrm{mM})$, superoxide dismutase (350 unit/mL), and catalase $(100 \mu \mathrm{g} / \mathrm{mL})$ were dissolved in the buffer $(2 \mathrm{~mL})$. The reaction mixture was preincubated at $37^{\circ} \mathrm{C}$ for $3 \mathrm{~min}$ and the reaction was initiated by the addition of NADH ( 1 $\mathrm{mM})$. In the case of $\mathrm{P} 450_{\mathrm{BM} 3}$, the enzyme $(2 \mu \mathrm{M})$, substrate $(1 \mathrm{mM})$, and superoxide dismutase (350 unit $/ \mathrm{mL}$ ) were dissolved in buffer. The reaction was initiated by the addition of NADPH $(1 \mathrm{mM})$. All of the substrates were added from a stock solution (100 $\mathrm{mM}$ in $\mathrm{MeOH})$. Control reactions were carried out without enzymes, and separately, without NADPH or NADH. All of the reaction mixtures were incubated at $37^{\circ} \mathrm{C}$ for $1 \mathrm{~h}$ and quenched by adding ethyl acetate. The aqueous phase was saturated with $\mathrm{NaCl}$ and extracted with ethyl acetate $(2 \mathrm{~mL} \times 2)$. Alternatively, the reaction mixture was extracted by Bond-Elut $\mathrm{C} 18$ cartridges as described above. The organic extract was dried over anhydrous $\mathrm{Na}_{2} \mathrm{SO}_{4}$ and evaporated to $50-100 \mu \mathrm{L}$ under a stream of nitrogen at room temperature for GC-MS analysis of a $3.0 \mu \mathrm{L}$ aliquot. TMS ethers, formed by adding MSTFA $(50 \mu \mathrm{L})$ to the extract residue and heating for $30 \mathrm{~min}$ at 80 ${ }^{\circ} \mathrm{C}$, were analyzed with a $1.0 \mu \mathrm{L}$ aliquot by GC-MS.

For the incubations with human enzymes, the incubation procedure was slightly modified from the assay protocol provided by Biocatalytics, Inc. The reaction buffer mixture provided by the vendor was dissolved in deionized water. To the solution was added $\alpha$-thujone $(100 \mathrm{mM}$ in $\mathrm{MeOH})$. After incubation at $37^{\circ} \mathrm{C}$ for $3 \mathrm{~min}$, the reaction was initiated by addition of the enzyme dissolved in deionized water. The final reaction volume was $1 \mathrm{~mL}$, containing enzyme $(1 \mu \mathrm{M})$ and substrate $(1 \mathrm{mM})$. The reaction mixtures were incubated at $37^{\circ} \mathrm{C}$ for $1 \mathrm{~h}$ before being extracted with Bond-Elut cartridges $\mathrm{C} 18$.

\section{$\mathrm{P}^{4} 50_{\text {cam }}$ Incubations in $\left[{ }^{2} \mathrm{H}\right]_{2} \mathrm{O}$}

The buffer was $100 \mathrm{mM}$ phosphate buffer in $\left[{ }^{2} \mathrm{H}\right]_{2} \mathrm{O}, \mathrm{pH} 7.4\left(37^{\circ} \mathrm{C}\right)$. The camphor present in the $\mathrm{P} 450_{\text {cam }}$ sample was removed prior to use by two passages through a PD-10 column eluted with $\left[{ }^{2} \mathrm{H}\right]_{2} \mathrm{O}$ buffer. The $\mathrm{H}_{2} \mathrm{O}$ in putidaredoxin and putidaredoxin reductase was also exchanged with $\left[{ }^{2} \mathrm{H}\right]_{2} \mathrm{O}$ by passage through a PD-10 column. $\alpha$-Thujone $(1 \mathrm{mM})$ was added from a stock solution (100 mM in $\left.\mathrm{CH}_{3} \mathrm{CN}\right)$, superoxide dismutase (375 unit $\left./ \mathrm{mL}\right)$, catalase $(100 \mu \mathrm{g} / \mathrm{mL})$, and NADH were added in $\left[{ }^{2} \mathrm{H}\right]_{2} \mathrm{O}$ stock solution. The reaction and the reaction mixture extraction were performed according to the procedures described above.

\section{Determination of Extraction Factors and GC-MS Response Factors for Thujone Metabolites}

To determine the extraction factors of thujone metabolites, a mixture of $\alpha$-thujone and authentic metabolite standards in $\mathrm{MeOH}(50 \mu \mathrm{L})$ was added to the buffer $(2 \mathrm{~mL})$ and vortexed before being extracted with ethyl acetate $(2 \mathrm{~mL} \times 2)$ or Bond-Elut $\mathrm{C} 18$ cartridges. The organic extract was dried over anhydrous $\mathrm{Na}_{2} \mathrm{SO}_{4}$, evaporated under a stream of nitrogen at room temperature, and reconstituted to $50 \mu \mathrm{L}$. The samples before and after the extraction were analyzed by GCMS. To determine the GC-MS response factors of thujone metabolites, solutions (0.1-4 mM in EtOAc) of each authentic metabolite were prepared and analyzed by GC-MS via a $3 \mu \mathrm{L}$ 
aliquot. The GC-MS integration area was correlated to the corresponding concentration by a $1^{\text {st }}$ order equation.

\section{RESULTS}

\section{Extraction Factors and GC-MS Response Factors of Thujone Metabolites}

The recovery factors for thujone metabolites from the incubation solution were experimentally determined. A mixture of the metabolite standards was dissolved in the incubation buffer and was then extracted with ethyl acetate or Bond-Elut C18 cartridges. The concentration and percentage of each metabolite were determined by GC-MS before and after the extraction (Table S1). The recovery factor was $>65 \%$ for each metabolite by ethyl acetate extraction and $>80 \%$ by solid phase extraction. The percentage of each metabolite was essentially the same before and after the extraction, indicating that there was no bias for any component in the extraction process.

To determine the response factor of each metabolite on GC-MS, metabolite standards of various concentrations were injected into the GC-MS in a fixed volume $(3 \mu \mathrm{L})$. Fig. S1 shows that all of the compounds responded proportionately to their concentration. All the compounds except carvacrol have a factor of around 4 between their GC-MS response and their actual concentration, which reflects their similar chemical structures. The factor for the aromatic compound carvacrol is about 2 -fold higher than that for its non-aromatic analogues. This result indicates that the real concentration of each metabolite in the solution is properly represented by its proportional response on GC-MS except that of carvacrol, which should be divided by a factor of 2 in comparison to other metabolites.

\section{Oxidation of $\alpha$-Thujone by Bacterial Enzymes}

We previously demonstrated the utility of thujone stereoisomers as $\mathrm{P} 450$ diagnostic substrates (14), but report here methodological improvements that update those results. $\alpha$ - and $\beta$-thujone were incubated with $\mathrm{P} 450_{\text {cam }}$ and $\mathrm{P} 450_{\mathrm{BM} 3}$. To suppress possible substrate oxidation or $\mathrm{P} 450$ degradation by hydrogen peroxide or superoxide, both of which are formed through uncoupled turnover of P450 enzymes, catalase and superoxide dismutase were included in the reaction mixture. Control reactions did not show any oxidation products in the absence of either the P450 enzyme or NADH/NADPH.

The reaction of $\alpha$-thujone with $\mathrm{P} 450_{\mathrm{BM} 3}$ yielded $8 \%$ of 7-hydroxy- $\alpha$-thujone, $0.3 \%$ of 7,8 dehydro- $\alpha$-thujone, $4.2 \%$ of 2-hydroxy- $\alpha$-thujone, $80.2 \%$ of 4-hydroxy- $\alpha$-thujone (the major product), $4.7 \%$ of 4 -hydroxy- $\beta$-thujone, and $0.6 \%$ of 4,10 -dehydro-thujone (Scheme 2 , Table 1). The ring-opened product from the radical intermediate, 5-hydroxy-5-isopropyl-2-methyl-2cyclohexen-1-one, was produced in $0.1 \%$ yield. As shown previously by chemical experiments (24), carvacrol is the principal product expected in solution from a 4-cationic intermediate. This compound was not detected in our previous work due to the low sensitivity of the flame ionization detector for this compound, but after switching to GC-MS it was detected here in $0.4 \%$ yield. The observation of carvacrol in the incubation mixture was further confirmed by comparing a TMS-derivatized sample with a TMS-derivatized authentic sample. The overall conversion of $\alpha$-thujone by $\mathrm{P} 450_{\mathrm{BM} 3}$ under these conditions was $32 \%$. The stereochemical inversion ratio at C-4 was 17/1 (4-hydroxy- $\alpha$-thujone/4-hydroxy- $\beta$-thujone) (Table 2).

The reaction of $\alpha$-thujone with $\mathrm{P} 450_{\text {cam }}$ afforded the same products but in different proportions: $75.9 \%$ of 7 -hydroxy- $\alpha$-thujone, $13.6 \%$ of 7,8-dehydro- $\alpha$-thujone, $0.3 \%$ of 2 -hydroxy- $\alpha$ thujone, $6.1 \%$ of 4 -hydroxy- $\alpha$-thujone, $0.4 \%$ of 4 -hydroxy- $\beta$-thujone, $0.02 \%$ of the ringopened product, $0.1 \%$ of 4,10 -dehydrothujone, and $0.15 \%$ of carvacrol. The conversion was $85 \%$ based on the starting $\alpha$-thujone detected in the reaction mixture. The stereochemical 
inversion ratio was $15 / 1$. In contrast to the reaction of $\alpha$-thujone with $\mathrm{P} 450_{\mathrm{BM} 3}$, the reaction of $\alpha$-thujone with $\mathrm{P} 450_{\text {cam }}$ occurred mainly at C-7 instead of C-4. The ratio between the total C-4 and C-7 oxidation products was $10 / 1$ for $\mathrm{P} 450_{\mathrm{BM} 3}$ and $1 / 13$ for $\mathrm{P} 450_{\text {cam }}$, respectively.

\section{Oxidation of $\beta$-Thujone by Bacterial Enzymes}

The reaction of $\beta$-thujone with $\mathrm{P} 450_{\mathrm{BM} 3}$ yielded $13.3 \%$ of 7 -hydroxy- $\beta$-thujone, $0.5 \%$ of 7,8 dehydro- $\beta$-thujone, $8.6 \%$ of 2 -hydroxy- $\beta$-thujone, $0.6 \%$ of 4 -hydroxy- $\alpha$-thujone, $62.1 \%$ of 4 hydroxy- $\beta$-thujone, $0.05 \%$ of the ring-opened product, $0.14 \%$ of 4,10 -dehydrothujone, and $0.1 \%$ of carvacrol (Scheme 2, Table 1). The overall conversion of $\beta$-thujone by $\mathrm{P} 450_{\mathrm{BM} 3}$ under these conditions was $42 \%$. The stereochemical inversion ratio was $1 / 104$ (Table 2).

The reaction of $\beta$-thujone with $\mathrm{P} 450_{\text {cam }}$ yielded $2.4 \%$ of 7 -hydroxy- $\beta$-thujone, $0.5 \%$ of 7,8 dehydro- $\beta$-thujone, $0.1 \%$ of 2 -hydroxy- $\beta$-thujone, $0.09 \%$ of 4 -hydroxy- $\alpha$-thujone, $95.3 \%$ of 4 hydroxy- $\beta$-thujone, $0.1 \%$ of the ring-opened product(s), $0.1 \%$ of 4,10 -dehydrothujone, and $0.2 \%$ of carvacrol. The overall conversion of $\beta$-thujone by $\mathrm{P} 450_{\text {cam }}$ under these conditions was $48 \%$ (Table 1). The stereochemical inversion ratio was $1 / 1059$ (Table 2). The much lower stereochemical inversion in the oxidation of $\beta$-thujone than in that of $\alpha$-thujone is consistent with the stereoselective reduction of chemically-generated thujone radicals by thiophenol (24), a reaction that greatly favors addition of the hydrogen from the $\alpha$-face.

\section{Oxidation of $7\left[^{2} \mathrm{H}\right]-\alpha-$ Thujone by $\mathrm{P}^{450} 0_{\text {cam }}$}

In order to shift metabolism from the $\mathrm{C}-7$ to the $\mathrm{C}-4$ position in enzymes such as $\mathrm{P} 450_{\text {cam }}$, thus amplifying the signals due to oxidation of the carbon of interest through metabolic switching, $7\left[{ }^{2} \mathrm{H}\right]-\alpha$-thujone was synthesized from 7-hydroxy- $\alpha$-thujone by trifluoroborane-catalyzed deuterium triethylsilane reduction (Scheme 1). When TFA was used instead of $\mathrm{BF}_{3}$, the trifluoroacetate of 7-hydroxythujone was formed but not reduced under the reaction conditions.

The reaction of $7\left[{ }^{2} \mathrm{H}\right]-\alpha$-thujone with $\mathrm{P} 450_{\text {cam }}$ afforded $31.4 \%$ of 7 -hydroxy- $\alpha$-thujone, $8.6 \%$ of 7,8-dehydro- $\alpha$-thujone, $1.6 \%$ of 2 -hydroxy- $\alpha$-thujone, $33.8 \%$ of 4 -hydroxy- $\alpha$-thujone, $1.3 \%$ of 4-hydroxy- $\beta$-thujone, $0.04 \%$ of the ring-opened product, $1 \%$ of 4,10 -dehydrothujone, and $0.8 \%$ of carvacrol. The formation of carvacrol and the ring-opened product from the radical intermediate were further confirmed by the corresponding molecular ions, which were one unit higher than those of the undeuterated samples, and by the corresponding fragmentations in their mass spectra. The conversion was $70 \%$ based on the starting $7\left[{ }^{2} \mathrm{H}\right]-\alpha$-thujone detected in the reaction mixture. In contrast to the reaction of $\alpha$-thujone with $\mathrm{P} 450_{\text {cam }}$, the reaction of 7 $\left[{ }^{2} \mathrm{H}\right]-\alpha$-thujone with $\mathrm{P} 450_{\text {cam }}$ shifted significantly from the $\mathrm{C}-7$ to the $\mathrm{C}-4$ position, as expected from the operation of a deuterium isotope effect on the hydroxylation reaction at $\mathrm{C}-7$. The ratio of C-4 to C-7 oxidation products was $1 / 1$ for $7\left[^{2} \mathrm{H}\right]-\alpha$-thujone, 13 -fold higher at $\mathrm{C}-4$ than the $1 / 13$ ratio obtained with undeuterated $\alpha$-thujone. The ring-opened product from the radical intermediate increased about 2 -fold in the oxidation of $7\left[{ }^{2} \mathrm{H}\right]-\alpha$-thujone compared to its formation from non-deuterated $\alpha$-thujone (Table 3 ). Furthermore, the stereochemical inversion ratio (26/1) exhibited about the same shift relative to that for the oxidation of undeuterated $\alpha$ thujone (15/1) (Table 2).

\section{Oxidation of $\alpha$-Thujone and $7\left[{ }^{2} \mathrm{H}\right]-\alpha-$ Thujone by the $\mathrm{P} 450_{\text {cam }}$ L244A Mutant}

The reaction of $\alpha$-thujone with the P450 cam mutant L244A was investigated to explore the influence of a small increase in the dimensions of an otherwise essentially identical active site cavity on the radical clock reaction. The reaction afforded $83 \%$ of 7-hydroxy- $\alpha$-thujone, $9.7 \%$ of 7,8-dehydro- $\alpha$-thujone, $2.4 \%$ of 2-hydroxy- $\alpha$-thujone, $2.1 \%$ of 4-hydroxy- $\alpha$-thujone, $1.1 \%$ of 4-hydroxy- $\beta$-thujone, $0.02 \%$ of the ring-opened product, $0.06 \%$ of 4,10 -dehydrothujone, and $0.16 \%$ of carvacrol (Table 3 ). While the C-7 oxidation product, 7-hydroxy- $\alpha$-thujone, was the major product in both the L244A and wild-type oxidations, the product distributions from 
oxidation at the C-4 and C-2 positions were somewhat different between these two enzymes. Compared to the wild-type $\mathrm{P} 450_{\text {cam }}$, the L244A mutant produced more C-2 oxidation product ( $2.4 \%$ vs $0.3 \%$ ), and the C-4 stereochemical inversion in the L244A oxidation gave a $2 / 1$ stereoisomer ratio, a value 7.5 -fold higher than the 15/1 ratio observed in the wild-type oxidation.

Oxidation of $7\left[{ }^{2} \mathrm{H}\right]-\alpha$-thujone by the $\mathrm{P} 450_{\text {cam }}$ L244A mutant afforded $41.5 \%$ of 7 -hydroxy- $\alpha$ thujone, $7 \%$ of 7,8-dehydro- $\alpha$-thujone, $11.9 \%$ of 2-hydroxy- $\alpha$-thujone, $10.8 \%$ of 4-hydroxy$\alpha$-thujone, $6.9 \%$ of 4 -hydroxy- $\beta$-thujone, $0.04 \%$ of the ring-opened product(s), $0.3 \%$ of 4,10 dehydrothujone, and $0.8 \%$ of carvacrol (Table 3 ). The conversion was $69 \%$ based on the starting $7\left[{ }^{2} \mathrm{H}\right]-\alpha$-thujone detected in the reaction mixture. The ratio between the $\mathrm{C}-4$ and $\mathrm{C}-7$ oxidation products is $1 / 2.5$ for $7\left[{ }^{2} \mathrm{H}\right]$ - $\alpha$-thujone, 11 -fold higher than the ratio of $1 / 27$ for undeuterated $\alpha$-thujone (Table 2). The ring-opened product from the radical intermediate increased 2-fold in the oxidation of $7\left[{ }^{2} \mathrm{H}\right]-\alpha$-thujone compared to its formation from undeuterated $\alpha$-thujone, but the $\mathrm{C}-4$ stereochemical inversion ratio was little altered.

\section{Effect of $\mathrm{pH}$ on $\alpha$-Thujone Metabolite Distribution}

To examine the effect of $\mathrm{pH}$ on the product distribution, the reaction of $\mathrm{P} 450_{\text {cam }}$ with $\alpha$-thujone was conducted under four $\mathrm{pH}$ conditions ranging from $\mathrm{pH} 6.5$ to $\mathrm{pH} 8.0(100 \mathrm{mM}$ phosphate buffer). The metabolite distributions under these conditions are summarized in Table S2. Only minor differences were observed within the indicated $\mathrm{pH}$ range. The conversion yield at $\mathrm{pH}$ $7.4(80.8 \%)$ was slightly higher than at other $\mathrm{pH}$ conditions. A nominal change was also observed in the $\mathrm{C} 4$ product distribution. The yield of $4 \mathrm{OH} \beta \mathrm{T}$ increased $26 \%$ from $\mathrm{pH} 6.5$ to $\mathrm{pH} 8.0$ and, correspondingly, the yield of $4 \mathrm{OH \alpha T}$ decreased $7 \%$ and the yield of ROP decreased $29 \%$. One olefinic product, $410 \mathrm{DHT}$, suffered a $40 \%$ decrease in yield, and the cation product, carvacrol, an $8 \%$ increase in yield.

\section{$\left[{ }^{2} \mathrm{H}\right]_{2} \mathrm{O}$ Effect on $\alpha$-Thujone Metabolite Distribution}

The reaction of $\mathrm{P}^{4} 50_{\text {cam }}$ with $\alpha$-thujone in a highly deuterated medium $\left(>99 \%\left[{ }^{2} \mathrm{H}\right]_{2} \mathrm{O}\right)$ was investigated to explore the role of the ferric hydroperoxide ( $\left.\mathrm{Fe}^{\mathrm{III}}-\mathrm{OOH}\right)$ precursor of the ferryl $\left(\mathrm{Fe}^{\mathrm{IV}}=\mathrm{O}\right)$ intermediate as a hydroxylating species. The metabolite distributions under $\mathrm{H}_{2} \mathrm{O}$ and $\left[{ }^{2} \mathrm{H}\right]_{2} \mathrm{O}$ conditions are summarized in Table S3. No significant differences were observed as a result of carrying out the reaction in a deuterated medium. The very small changes observed probably stem from the difference between $\mathrm{pD}$ and $\mathrm{pH}(\mathrm{pD}=\mathrm{pH}+0.41)(29)$.

\section{Oxidation of $\alpha$-Thujone by Human P450 Enzymes}

Six human enzymes were examined as catalysts of $\alpha$-thujone to further explore the extent to which active site structure influences the radical recombination and dehydrogenation reactions. All six human enzymes catalyzed the oxidation of $\alpha$-thujone, but only CYP2D6 and CYP3A4 gave sufficient conversion of the substrate to metabolites within a 1-h incubation time to enable a detailed analysis. The other four enzymes, CYP1A2, $-2 \mathrm{C} 9,-2 \mathrm{C} 19$, and $-2 \mathrm{E} 1$, gave only $\sim 1 \%$ conversion under these experimental conditions and the data was only suitable for identification of the major metabolites (Table 4).

CYP3A4 oxidized $\alpha$-thujone to $49.6 \%$ of 7-hydroxy- $\alpha$-thujone (the major product), $3.8 \%$ of 7,8-dehydro- $\alpha$-thujone, $2.2 \%$ of 2-hydroxy- $\alpha$-thujone, $25.8 \%$ of 4 -hydroxy- $\alpha$-thujone, $7.4 \%$ of 4-hydroxy- $\beta$-thujone, and $3.3 \%$ of carvacrol (Table 4 ). The product of ring opening of the C-4 radical intermediate, 5-hydroxy-5-isopropyl-2-methyl-2-cyclohexen-1-one, accounted for $0.3 \%$ of the product yield. 4,10-Dehydrothujone was not detected in the CYP3A4 reaction. The stereochemical inversion ratio was 3.6/1 (Table 5). The ratio between the C-4 and C-7 oxidation products was 1/1.3. 
The oxidation of $\alpha$-thujone by CYP2D6 yielded $58.7 \%$ of 7-hydroxy- $\alpha$-thujone, $9.1 \%$ of 7,8dehydro- $\alpha$-thujone, $17.8 \%$ of 4-hydroxy- $\alpha$-thujone, $7.1 \%$ of 4 -hydroxy- $\beta$-thujone, and $4.3 \%$ of carvacrol (Table 4 ). The ring-opened product was produced in $0.26 \%$ yield. $4,10-$ Dehydrothujone, which was observed in the reactions of the bacterial enzymes, was not detected in the reaction of CYP2D6. 2-Hydroxy- $\alpha$-thujone was also not detected. The stereochemical inversion ratio was $2.5 / 1$ (Table 5). The ratio between the $\mathrm{C}-4$ and $\mathrm{C}-7$ oxidation products was 1/2.7.

The only two products detected in the oxidation of $\alpha$-thujone with CYP1A2 due to the relatively low turnover of the substrates were 4-hydroxy- $\alpha$-thujone (21.7\%) and 4-hydroxy- $\beta$-thujone (78.4\%). A 1-h reaction of $\alpha$-thujone with CYP2C9 produced $18.1 \%$ of 7-hydroxy- $\alpha$-thujone, $19.0 \%$ of 4 -hydroxy- $\alpha$-thujone, and $62.9 \%$ of 4 -hydroxy- $\beta$-thujone. The stereochemical inversion ratios for these two proteins were $1 / 3.6$ and was $1 / 3.3$, respectively. Similarly, the oxidation of $\alpha$-thujone by CYP2C19 produced $14.1 \%$ of 7-hydroxy- $\alpha$-thujone, $19.5 \%$ of 4 hydroxy- $\alpha$-thujone, and $66.5 \%$ of 4 -hydroxy- $\beta$-thujone (Table 4$)$. The stereochemical inversion ratio was $1 / 3.4$ (Table 5). The ratio between the C-4 and C-7 oxidation products was 6.1/1. Finally, a 1-h reaction of $\alpha$-thujone with CYP2E1 yielded $15.5 \%$ of 7-hydroxy- $\alpha$-thujone, $19.4 \%$ of 4 -hydroxy- $\alpha$-thujone, and $65.1 \%$ of 4 -hydroxy- $\beta$-thujone. The stereochemical inversion ratio was $1 / 3.4$ and the ratio between the $\mathrm{C}-4$ and $\mathrm{C}-7$ oxidation products was 5.5/1.

CYP1A2 thus primarily oxidized $\alpha$-thujone at $\mathrm{C}-4$ to give the two 4-hydroxythujone isomers whereas CYP2C9, CYP2C19, and CYP2E1 primarily catalyzed similar C-4 oxidation but also produced a significant amount of the 7-hydroxy- $\alpha$-thujone metabolite. The radical recombination rates, C-4 methyl stereochemistry ratio, C-4 to C-7 product ratio, and ratio of C-4 radical to cation products in the oxidation of $\alpha$-thujones by human P450s, as available, are listed in Table 4.

\section{DISCUSSION}

Analysis of the products formed on oxidation of the radical clock probes $\alpha$ - and $\beta$-thujone by $\mathrm{P} 450_{\text {cam }}$ and $\mathrm{P} 450_{\mathrm{BM} 3}$ has resulted in identification of several minor products in addition to those previously reported (14). The new products are 2 -hydroxy- $\alpha$-thujone, 2 -hydroxy- $\beta$ thujone, 7,8-dehydro- $\alpha$-thujone, 7,8-dehydro- $\beta$-thujone, and carvacrol (Scheme 2 ). The 2 hydroxythujone and the 7,8-dehydrothujone isomers were detected in earlier studies of the metabolism of $\alpha$ - and $\beta$-thujone by mammalian liver $(26,30,31)$, but were not specifically identified in the previous work with purified bacterial enzymes (14). As indicated by the "Other" column in Table 1, a few small unidentified peaks remain in the gas chromatogram, but the percent of the metabolites represented by these products has greatly decreased compared to the earlier study: from 6 to $1.5 \%$ for $\mathrm{P} 450_{\mathrm{BM} 3}$ and $\alpha$-thujone, 25 to $14.6 \%$ for $\mathrm{P} 450_{\mathrm{BM}-3}$ and $\beta$-thujone, 19 to $3.5 \%$ for $\mathrm{P}_{450}$ cam and $\alpha$-thujone, and 3 to $1.2 \%$ for $\mathrm{P} 450_{\text {cam }}$ and $\beta$-thujone.

P450 $0_{\text {cam }}$ oxidizes $\alpha$-thujone primarily at the 7 position, producing 7-hydroxy- $\alpha$-thujone (75.9\%) and 7-dehydro- $\alpha$-thujone (13.6\%). Oxidation at C-4 accounts for $6.8 \%$, oxidation at C-2 for $0.3 \%$, and unidentified minor products for $3.5 \%$ (Table 1). Interestingly, oxidation of the opposite end of the substrate dominates in the reaction of $\mathrm{P} 450_{\text {cam }}$ with $\beta$-thujone (Table 1). In this instance, $\mathrm{C}-7$ oxidation accounts for only $2.9 \%$, oxidation at $\mathrm{C}-4$ for slightly under $96 \%$, and oxidation at $\mathrm{C}-2$ for $0.1 \%$. Inversion of the stereochemistry of C-4, which bears a single methyl group, thus causes the thujone to completely invert its preferred orientation in the $\mathrm{P} 450_{\text {cam }}$ active site.

Cytochrome $\mathrm{P} 450_{\mathrm{BM} 3}$, in contrast, is not sensitive to the stereochemistry of the 4-methyl group. Thus, 4-hydroxylation is the predominant reaction in the oxidation of both $\alpha$ - and $\beta$-thujones (Table 1). However, the $\mathrm{P}^{4} 50_{\mathrm{BM} 3}$ reaction is less regioselective, as there is a considerable 
amount of oxidation at C-7 ( $\alpha$-thujone, $8.3 \%, \beta$-thujone $13.8 \%$ ) and $\mathrm{C}$-2 $(\alpha$-thujone $4.2 \%, \beta$ thujone $8.6 \%$ ). The oxidation of $\alpha$-thujone by $\mathrm{P} 450_{\mathrm{BM} 3}$ occurs $8.3 \%$ at $\mathrm{C}-7,86 \%$ at $\mathrm{C}-4$, and $4.2 \%$ at $\mathrm{C}-2$, and that of $\beta$-thujone $13.8 \%$ at C-7, $63 \%$ at $\mathrm{C}-4$, and $8.6 \%$ at C-2.

The use of thujones as mechanistic probes depends on their oxidation at C-4, so the high degree of oxidation at C-7 rather than $\mathrm{C}-4$ in the reaction of $\mathrm{P} 450_{\text {cam }}$ with $\alpha$-thujone diminishes the sensitivity of this compound as a radical clock substrate for this enzyme. To overcome this defect, we synthesized 7-deuterated $\alpha$-thujone in the expectation that a primary isotope effect on 7-oxidation would shift the oxidation process to the mechanistically more informative C-4 site. This was, indeed, the result, although the isotope effect appears to be partially masked because the C-7 metabolites decreased from $89.5 \%$ to $40 \%$, a net deuterium isotope effect of 2.2 (Table 3). Nevertheless, this isotope effect on the major pathway produced a large increase in the mechanistically interesting minor metabolites. Thus, C-4 oxidation increased 5.5-fold and C-2 hydroxylation 5-fold. Thus, the 7-deuterated probe makes it possible to enhance the proportion of the oxidation at the mechanistically informative $\mathrm{C}-4$ position in situations where C-7 hydroxylation competes too effectively with C-4 hydroxylation.

The radical recombination rates for hydroxylation at C-4 can be calculated from the data in Table 1 using the equation below, given the rate of $4.4 \times 10^{7}$ for ring opening of the thujone $\mathrm{C}-4$ radical determined by our earlier calibration studies (24):

$$
\mathrm{k}_{1}=\left[\frac{4 \mathrm{OH} \alpha \mathrm{T}+4 \mathrm{OH} \beta \mathrm{T}}{\mathrm{ROP}}\right]\left[\times 4.4 \times 10^{7} \mathrm{~s}^{-1}\right]
$$

The recombination rates calculated for the various combinations of enzyme and substrate are given in Table 2 . Thus, the radical recombination rate for $\mathrm{P}^{4} 50_{\mathrm{BM} 3}$ with $\alpha$-thujone is $(3.7 \pm$ $1.4) \times 10^{10} \mathrm{~s}^{-1}$ and with $\beta$-thujone $(12.5 \pm 3.0) \times 10^{10} \mathrm{~s}^{-1}$. The corresponding recombination rate for $\mathrm{P} 450_{\text {cam }}$ with $\alpha$-thujone is $(2.0 \pm 0.6) \times 10^{10} \mathrm{~s}^{-1}$, and with $\beta$-thujone $(9.5 \pm 1.2) \times$ $10^{10} \mathrm{~s}^{-1}$. These revised rates differ somewhat from those previously reported: $\mathrm{P} 450_{\mathrm{BM}} 3$ with $\alpha$-thujone $0.6 \times 10^{10} \mathrm{~s}^{-1}$ and with $\beta$-thujone $1.6 \times 10^{10} \mathrm{~s}^{-1}$; and $\mathrm{P} 450_{\text {cam }}$ with $\alpha$-thujone $0.2 \times$ $10^{10} \mathrm{~s}^{-1}$ and with $\beta$-thujone $2.8 \times 10^{10} \mathrm{~s}^{-1}(14)$. The new rates are higher by a factor of from 3.4 ( $\mathrm{P} 450_{\text {cam }}$ with $\beta$-thujone) to 10 ( $\mathrm{P} 450_{\text {cam }}$ with $\alpha$-thujone). These differences reflect changes in the product ratios due to the improved GC-MS methodology. More importantly, the 7deuterated probe makes it possible to enhance the proportion of the oxidation by $\mathrm{P} 450_{\text {cam }}$ at the mechanistically informative $\mathrm{C}-4$ position and thus to improve the accuracy of the measurements. All the rates nevertheless remain within the range expected for radical intermediate reactions and support the reaction mechanism in Scheme 3.

The radical recombination rates show substantial substrate- and enzyme-dependent variation. The rates determined from the oxidation of $\alpha$-thujone by $\mathrm{P} 450_{\text {cam }}$ and $\mathrm{P} 450_{\mathrm{BM}}$ thus differ by a factor of 1.9 , and the rates from the oxidation of $\alpha$ - and $\beta$-thujone by $\mathrm{P} 450_{\text {cam }}$ by a factor of 4.8. This is consistent with the accumulated evidence employing a range of probes that, within limits, the measured recombination rate is not constant but is substrate and enzyme dependent. The differences in the recombination rates could reflect true differences in recombination rates or, according to the two-transition state paradigm championed by Shaik (6), a change in the proportions of the reaction that occur from the high- and low-spin transition state pathways of the ferry species.

To explore further the substrate and enzyme dependence of the recombination rates, we have investigated the oxidation of $\alpha$-thujone and $7-\left[{ }^{2} \mathrm{H}\right]$ - $\alpha$-thujone by the L244A mutant of $\mathrm{P}_{45} 0_{\text {cam. }}$. In the L244A mutant, three atoms are removed from a protein side-chain that lines one side of the active site pocket. Previous studies of the substrate specificity of the L244A mutant have shown that it possesses a diminished catalytic activity but accepts larger substrates than the wild-type enzyme (32). A crystal structure of the L244A mutant is not available, but 
modeling of the active site suggests that the cavity is modestly expanded but otherwise little altered. A comparison of the oxidation of the two probe substrates by wild-type $\mathrm{P} 450_{\text {cam }}$ and its L244A mutant reveals interesting differences. The ratio of C-7 to C-4 metabolism remains essentially unaltered, with $92.7 \%$ (versus $89.5 \%$ for wild-type) of the reaction in the L244A mutant occurring at C-7 and 3.4\% (versus $6.8 \%$ in wild-type) at C-4 (Table 3). However, 2hydroxylation greatly increases from 0.3 to $2.4 \%$ (an 8-fold change). The 7-deuterated probe again causes a shift from C-7 to C-2 and C-4 oxidation, with a 1.9-fold (versus 2.2-fold for wild-type) decrease in C-7 oxidation, a 5-fold (versus 5.3-fold for wild-type) increase in C-2 oxidation, and a 5.5-fold (versus 5.4-fold in wild-type) increase in C-4 oxidation (Table 1). The isotope effect shifts are therefore similar for the wild-type and mutant.

The most interesting difference in the L244A mutant is in the extent of inversion of stereochemistry of the methyl-substituted C-4 carbon. The ratio of 4-hydroxylated thujone isomers in the $\mathrm{P} 450_{\mathrm{BM}}{ }^{-c a t a l y z e d}$ oxidation of $\alpha$-thujone was 17:1 and of $\beta$-thujone 1:104 (Table 2). The corresponding value for the oxidation of $\alpha$-thujone by P450 cam was $15: 1$, and for $\beta$-thujone 1:1059, indicating that very little inversion occurred. However, in the case of the L244A mutant with $\alpha$-thujone, the ratio of inverted to non-inverted 4-hydroxythujone metabolites was 2:1 (i.e., 33\% inversion), and for the 7-deuterated analogue was about the same (38\%). Thus, the L244A mutant allows a much greater rate of inversion of the methylsubstituted C-4 center during hydroxylation at this position. The original calibration studies indicated that trapping of a C-4 radical by hydrogen atom transfer from thiophenol gave essentially the same mixture of isomers regardless of whether the radical was generated with the methyl in the $\alpha$ - or $\beta$-orientation (24). In both cases, the $\alpha$ - to $\beta$-ratio was $\sim 6: 100$, indicating that the hydrogen trapping reaction occurred from an equilibrium isomeric mixture and greatly favored delivery of the hydrogen to C- 4 from the sterically less hindered $\alpha$-face. This preference is clearly abrogated by the radical recombination reaction of the $\mathrm{P} 450_{\text {cam }} \mathrm{L} 244 \mathrm{~A}$ mutant, as an equal amount of delivery of the hydroxyl group to the $\alpha$ - and $\beta$-faces is observed despite the fact that the hydrogen must be abstracted from the $\beta$-face. Thus, the increased volume or flexibility of the L244A active site allows a greater degree of substrate rotation prior to transfer of the hydroxyl group to the carbon.

The radical recombination rates for C-4 hydroxylation of $\alpha$-thujone by CYP2D6 and CYP3A4 were 0.34 and $0.48 \times 10^{10} \mathrm{~s}^{-1}$, respectively (Table 5). These values are somewhat smaller than the values obtained for oxidation of the same substrate by $\mathrm{P} 450_{\mathrm{cam}}\left(2 \times 10^{10} \mathrm{~s}^{-1}\right)$ and $\mathrm{P}_{5} 0_{\mathrm{BM} 3}\left(3.7 \times 10^{10} \mathrm{~s}^{-1}\right)$. Radical recombination rates could not be calculated for CYP1A2, CYP2C9, CYP2C19, and CYP 2E1 due to limiting amounts of enzyme and low turnover rates for $\alpha$-thujone. However, in all cases it has been possible to assess the extent to which the methylsubstituted C-4 center undergoes inversion of configuration during the hydroxylation reaction (Table 5). For all six human enzymes the extent of inversion is greater than for $\mathrm{P} 450_{\text {cam }}$ or $\mathrm{P}_{50} \mathrm{BM}_{\mathrm{BM}}$. Indeed, with all the human enzymes other than CYP2D6 and CYP3A4, the 4hydroxylated product with inverted stereochemistry is the dominant product. With CYP2D6 and CYP3A4, the major product is that with the original methyl stereochemistry, but even here methyl-substituted C-4 inversion occurs to a much larger extent than is seen with wild-type $\mathrm{P} 450_{\text {cam }}$ and $\mathrm{P}_{50} 0_{\mathrm{BM} 3}$ (Table 1). Interestingly, the L244A P450 cam mutant more closely resembles the mammalian enzymes in this regard, as inversion of the methyl stereochemistry is observed in $33 \%$ of the C-4 hydroxylated metabolite. These results are consistent with the intervention of a radical recombination mechanism with a radical species that has a lifetime comparable to, if somewhat longer than, those observed for the wild-type bacterial enzymes. The larger extent of methyl inversion may reflect the expected "looseness" of fit of $\alpha$-thujone

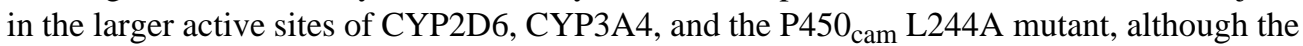
data do not specifically require this. The high degree of methyl inversion seen with the other human enzymes does provide direct evidence that the major (or exclusive) pathway of carbon hydroxylation proceeds through the carbon radical species. A cationic intermediate is 
inconsistent with this finding because the cation has been shown to rearrange efficiently to the aromatic product carvacrol (14).

In addition to 2-, 4-, and 7-hydroxylation, the oxidation of $\alpha$ - and $\beta$-thujone produces three desaturated metabolites: $\alpha$-(or $\beta$ )-7,8-dehydrothujone, 4,10-dehydrothujone, and carvacrol. The 7,8-dehydrogenation presumably reflects formation of a cation at C-7 by electron transfer or proton-coupled electron transfer from the initial C-7 radical to the enzyme. In agreement with this, substitution of a deuterium at C-7 decreases both 7-hydroxylation and 7-desaturation with approximately the same isotope effect on both reactions. This finding is consistent with other P450-mediated desaturations, which have been shown to exhibit a significant isotope effect when deuterium is located at the carbon from which the hydrogen is abstracted by the catalytic species, but not for deuterium at the carbon from which the hydrogen is lost as a proton (33-36). Thus, desaturation triggered by abstraction of a hydrogen from the C-8 methyl group is ruled out, in accord with the apparent absence of a C-8 hydroxylated metabolite.

4,10-Desaturation was observed previously with $\mathrm{P}_{450} 0_{\text {cam }}$ and $\mathrm{P}^{4} 50_{\mathrm{BM} 3}$ (14). A mechanism similar to that proposed for 7,8-desaturation was proposed for this reaction in which hydroxyl radical transfer to the $\mathrm{C}-4$ radical and ring opening of the radical clock to give the rearranged (ROP) product occur as competitive processes. In the previous studies, carvacrol was not detected despite a specific search for its presence using an authentic standard. In the present studies in which GC-MS rather than GC-FID was used as the analytical method, it has been possible to detect and quantitate this product. Carvacrol formation is significant because chemical studies demonstrated that carvacrol is quantitatively formed when the C-4 cation is generated in solution (14). Thus, carvacrol formation and possibly 4,10-dehydrogenation provide a measure of the extent of C-4 cation formation.

In all cases, radical recombination to give 4-hydroxylated thujones dominates the C-4 reaction, but small amounts of cation and desaturation products are obtained. For the purpose of quantitation, the 4,10-desaturated product is assumed here to arise via cation formation rather than by a second hydrogen atom abstraction by the ferryl species. In the oxidation of $\alpha$-thujone by $\mathrm{P} 450_{\mathrm{BM}}, \mathrm{C}-4$ radical recombination accounts for $84.9 \%$ of the product, whereas carvacrol and 4,10 -dehydrothujone account for only $1 \%$. Radical recombination is thus rapid relative to both ring opening and cation formation. The results for oxidation of $\beta$-thujone by $\mathrm{P} 450_{\mathrm{BM} 3}$ are similar, with C-4 radical recombination accounting for $62.7 \%$ of the products and the cation pathway for only $0.24 \%$ (Table 1 ). In the case of $\alpha$-thujone oxidation by $\mathrm{P}^{2} 50_{\text {cam }}$, recombination accounts for $6.5 \%$ and the cation pathway for $0.25 \%$ of the total products, and in that of $\beta$-thujone $95.4 \%$ and $0.3 \%$, respectively. When the 7 -deuterated substrate is used, $4-$ hydroxylation increases to $35.1 \%$ and carvacrol plus 4,10-dehydrothujone to $1.8 \%$. With the L244A mutant, the ratio for $\alpha$-thujone oxidation is $3.2 \%$ 4-hydroxylation and $0.22 \% \mathrm{C}-4$ cation formation, whereas with $7-\left[{ }^{2} \mathrm{H}\right]-\alpha$-thujone the corresponding values are $17.7 \% \mathrm{C}-4$ hydroxylation and $1.1 \% \mathrm{C}-4$ cation products. Inspection of these numbers indicates that the ratio of hydroxylation to $\mathrm{C}-4$ cation formation is not constant. The ratios (Table 2) vary from 15:1 for the L244A oxidation of $\alpha$-thujone to $318: 1$ for the oxidation of $\beta$-thujone by $\mathrm{P} 450_{\text {cam. }}$. The factors that control this 6- to 20-fold difference in partitioning of the C-4 intermediate into radical and cation pathways remain obscure, but could include the presence or absence of basic residues, the polarity of the active site, and the degree to which the C-4 radical is positioned for rebound hydroxy transfer from the heme iron atom. If the 4,10desaturated product is formed via a C-4 cation, the factors that that control whether it yields 4,10-dehydrothujone or carvacrol are likewise unknown. The possibility cannot be ruled out that the 4,10-desaturated product is formed by a second hydrogen abstraction from C-10 by the protonated ferryl species generated in the first hydrogen abstraction rather than via the cation. Nevertheless, the slight decrease in formation of 4-hydroxy- $\beta$-thujone paralleled by a corresponding slight increase in formation of the 4,10-dehydro product upon changing the $\mathrm{pH}$ 
of the $\mathrm{P} 450_{\text {cam }} / \alpha$-thujone incubation medium from 6.5 to 8.5 suggests that these two reactions are inversely linked by a process that involves an active site base.

The finding that there is no detectable alteration in the outcome of the oxidation process when the reaction is carried out in highly deuterated medium rather than in normal water provides strong support for a single ferryl oxidizing species and against a direct oxidative role for the ferric hydroperoxide ( $\left.\mathrm{Fe}^{\mathrm{III}}-\mathrm{OOH}\right)$ intermediate. Previous studies have shown that a hydrogenbonding network exists that delivers protons to the hydroperoxide to facilitate its cleavage to give the ferryl species (Fig. 1) (37,38). This network of hydrogen bonds is critical, as mutation of Thr252 to residues with non-hydrogen bonding side-chains leads to a high degree of uncoupling to produce $\mathrm{H}_{2} \mathrm{O}_{2}$ at the expense of ferryl formation and substrate oxidation (39-41). A recent crystal structure has provided evidence that the Thr252 hydroxyl serves as a hydrogen bond acceptor (42). Sligar and colleagues have examined the role of the hydrogen bonds in catalysis by determining the solvent deuterium isotope effect on each of the accessible kinetic steps of the reaction $(37,38)$. Their results have established that the second electron transfer, which is linked to protonation of the ferric hydroperoxide intermediate, exhibits a deuterium KSIE of 1.8 and is the only isotopically sensitive step in the catalytic cycle (37, 38). Replacement of the hydrogen bond network with deuterium atoms thus alters the rate of cleavage of the ferric hydroperoxide complex to give the ferryl species. If both the hydroperoxide and ferryl were involved in oxidation reactions and gave different products or product ratios, an alteration in the product profile associated with a shift from hydrogen to deuterium should be observed due to this solvent isotope effect. However, the data indicate that the oxidizing species is the same in deuterated and nondeuterated medium. Assuming that there is no change in the mechanism of oxygen activation by $\mathrm{P} 450_{\text {cam }}$ due to the use of $\alpha$ thujone rather than camphor, this finding suggests that the ferric hydroperoxide does not play a significant role in the oxidation of the substrate. This result is consistent with the report that mutation of Thr252 both suppresses camphor hydroxylation and greatly decreases epoxidation of a camphor analogue with a double bond (43), which also argues against a significant role for the ferric hydroperoxide species in normal hydrocarbon oxidation.

\section{CONCLUSIONS}

The radical recombination rates for 4-hydroxylation of $\alpha$ - and $\beta$-thujone by $\mathrm{P} 450_{\mathrm{BM} 3}$, $\mathrm{P} 450_{\text {cam }}$, the L244A P450 cam mutant, CYP3A4, and CYP2D6 range from a low of $0.34 \times$ $10^{10} \mathrm{~s}^{-1}$ to a high of $(12.5 \pm 3) \times 10^{10} \mathrm{~s}^{-1}$, well within the range for transition states of radical recombination reactions. In addition, $\mathrm{C}-4$ hydroxylation of the thujones is accompanied by a small extent of inversion of the C-4 methyl group, but this inversion in the L244A mutant accounts for $33 \%$ of the 4-hydroxylated product, implying a major role for the radical species in the reaction. Limited experimental results on human P450 enzymes show that the recombination rates for these enzymes are comparable to those for the bacterial proteins and reveal a particularly high extent of C-4 inversion, a finding strongly supportive of a radical mechanism. The C-4 dehydrogenation products 4,10-dehydrothujone and carvacrol, as well as the 7,8-dehydrothujones arising from C-7 dehydrogenation, can be rationalized by formation of C-4 and C-7 cations via electron transfer from the corresponding radicals to the ferryl species, although the two olefinic products could arise by a second hydrogen atom abstraction by the ferryl species. The observation that no changes occur in the product profiles when the aqueous medium is replaced by highly deuterated medium argues against involvement of the $\mathrm{P} 450_{\text {cam }}$ ferric hydroperoxide intermediate, a species that has been postulated to lead directly to cationic products $(20,23)$, in substrate oxidation. Overall, the results provide persuasive support for the view that carbon hydroxylation reactions by cytochrome $\mathrm{P} 450$ enzymes proceed via a radical rebound mechanism as shown in Scheme 3. 


\section{Supplementary Material}

Refer to Web version on PubMed Central for supplementary material.

\section{Acknowlegments}

We thank Andreas Verras for preparation of the L244A P450 cam mutant.

\section{REFERENCES}

1. Kagawa, N.; Waterman, MR. Regulation of steroidogenic and related P450s. In: Ortiz de Montellano, PR., editor. Cytochrome P450: Structure, Mechanism, and Biochemistry. 2nd Ed.. Plenum Press; New York: 1995. p. 419-442.

2. Capdevila, JH. Cytochrome P450 and the metabolism and bioactivation of arachidonic acid and eicosanoids. In: Ortiz de Montellano, PR., editor. Cytochrome P450: Structure, Mechanism, and Biochemistry. 3rd Ed.. Plenum Klewer; New York: 2005. p. 531-551.

3. Groves JT, McGlusky GA, White RE, Coon MJ. Aliphatic hydroxylation by highly purified liver microsomal cytochrome P450. Evidence for a carbon radical intermediate. Biochem. Biophys. Res. Commun 1978;81:154-160. [PubMed: 656092]

4. Ortiz de Montellano, PR.; De Voss, JJ. Substrate oxidation by cytochrome P450 enzymes. In: Ortiz de Montellano, PR., editor. Cytochrome P450: Structure, Mechanism, and Biochemistry. 3rd Ed.. Plenum Klewer; New York: 2005. p. 183-245.

5. Makris, TM.; Denisov, I.; Schlichting, I.; Sligar, SG. Activation of molecular oxygen by cytochrome P450. In: Ortiz de Montellano, PR., editor. Cytochrome P450: Structure, Mechanism, and Biochemistry. 3rd Ed.. Plenum Klewer; New York: 2005. p. 149-182.

6. Shaik, S.; De Visser, SP. Computational approaches to cytochrome P450 function. In: Ortiz de Montellano, PR., editor. Cytochrome P450: Structure, Mechanism, and Biochemistry. 3rd Ed.. Plenum Klewer; New York: 2005. p. 45-85.

7. Hjelmeland LM, Aronow L, Trudell JR. Intramolecular determination of primary kinetic isotope effects in hydroxylations catalyzed by cytochrome P450. Biochem. Biophys. Res. Commun 1977;76:541549. [PubMed: 1027445]

8. Groves GT, Subramanian DV. Hydroxylation by cytochrome P450 and metalloporphyrin models. Evidence for allylic rearrangement. J. Am. Chem. Soc 1984;106:2177-2181.

9. Oliw EH, Brodowsky ID, Hörnsten L, Hamberg M. Bis-allylic hydroxylation of polyunsaturated fatty acids by hepatic monooxygenases and its relation to the enzymatic and nonenzymatic formation of conjugated hydroxy fatty acids. Arch. Biochem. Biophys 1993;3000:434-439. [PubMed: 8424677]

10. Tanaka K, Kurihara N, Nakajima M. Oxidative metabolism of tetrachlorocyclohexenes, pentachlorocyclohexenes, and hexachlorocyclohexenes with microsomes from rat liver and house fly abdomen. Pestic. Biochem. Physiol 1979;10:79-85.

11. Ortiz de Montellano PR, Stearns RA. Timing of the radical recombination step in cytochrome P450 catalysis with ring-strained probes. J. Am. Chem. Soc 1987;109:3415-3420.

12. Bowry VW, Ingold KU. A radical clock investigation of microsomal cytochrome $\mathrm{P} 450$ hydroxylation of hydrocarbons. Rate of oxygen rebound. J. Am. Chem. Soc 1991;113:5699-5707.

13. Auclair K, Hu Z, Little DM, Ortiz de Montellano PR, Groves JT. Revisiting the mechanism of P450 enzymes using the radical clocks norcarane and spiro[2,5]bicyclooctane. J. Am. Chem. Soc 2002;124:6020-6027. [PubMed: 12022835]

14. He X, Ortiz de Montellano PR. Radical rebound mechanism in cytochrome P450-catalyzed hydroxylation of the multifaceted radical clocks $\alpha$ - and $\beta$-thujone. J. Biol. Chem 2004;279:3947939484. [PubMed: 15258138]

15. Cryle MJ, Stuthe JMU, Ortiz de Montellano PR, De Voss JJ. Cyclopropyl fatty acids implicate a radical but not a cation as an intermediate in $\mathrm{P}^{450}{ }_{\mathrm{BM}} 3$-catalyzed hydroxylations. Chem. Commun 2004:512-513.

16. Cryle MJ, Ortiz de Montellano PR, De Voss JJ. Cyclopropyl containing fatty acids as mechanistic probes for cytochrome P450. J. Org. Chem 2005;70:2455-2469. [PubMed: 15787531] 
17. Newcomb M, Toy PH. Hypersensitive radical probes and the mechanisms of cytochrome P450catalyzed hydroxylation reactions. Acc. Chem. Res 2000;33:449-455. [PubMed: 10913233]

18. Atkinson JK, Ingold KU. Cytochrome P450 hydroxylation of hydrocarbons: Variation in the rate of oxygen rebound using cyclopropyl radical clocks including two new ultrafast probes. Biochemistry 1993;32:9209-9214. [PubMed: 8369287]

19. Newcomb M, Le Tadic M-H, Putt DA, Hollenberg PF. An incredibly fast apparent oxygen rebound rate constant for hydrocarbon hydroxylation by cytochrome P450 enzymes. J. Am. Chem. Soc 1995;117:3312-3313.

20. Newcomb M, Le Tadic-Biadatti M-H, Chestney DL, Roberts ES, Hollenberg PF. A nonsynchronous concerted mechanism for cytochrome P450 catalyzed hydroxylation. J. Am. Chem. Soc 1995; 117:12085-12091.

21. Toy PH, Dhanabalasingam B, Newcomb M, Hanna IH, Hollenberg PF. A substituted hypersensitive radical probe for enzyme-catalyzed hydroxylations: synthesis of racemic and enantiomerically enriched forms and applications in a cytochrome P450-catalyzed oxidation. J. Org. Chem 1997;62:9114-9122.

22. Toy PH, Newcomb M, Coon MJ, Vaz ADN. Two distinct electrophilic oxidants effect hydroxylation in cytochrome P450-catalyzed reactions. J. Am. Chem. Soc 1998;120:9718-9719.

23. Newcomb M, Shen R, Choi S-Y, Toy PH, Hollenberg PF, Vaz ADN, Coon MJ. Cytochrome P450catalyzed hydroxylations of mechanistic probes that distinguish between radicals and cations. Evidence for cationic but not for radical intermediates. J. Am. Chem. Soc 2000;122:2677-2686.

24. He X, Ortiz de Montellano PR. $\alpha$ - and $\beta$-Thujone radical rearrangements and isomerizations. A new radical clock. J. Org. Chem 2004;69:5684-5789. [PubMed: 15307740]

25. Brieskorn CH, Schwack W. Epimerisierung von (-)-Thujon zu (+)-Thujon. Tet. Lett 1980;21:255256.

26. Sirisoma NS, Höld KM, Casida JE. $\alpha$ - and $\beta$-Thujones (herbal medicines and food additives): synthesis and analysis of hydroxy and dehydro metabolites. J. Agric. Food Chem 2001;49:1915-1921. [PubMed: 11308346]

27. Kainuma K, Watabe I, Tamura H. Preparation of optically active 4-hydroxy-1-p-menthenes for fragrant or flavor compositions. Jpn. Kokai Tokkyo Koho 1996:5.

28. De Voss JJ, Sibbesen O, Zhang Z, Ortiz de Montellano PR. Substrate docking algorithms and prediction of the substrate specificity of cytochrome P450 cam and its L244A mutant. J. Am. Chem. Soc 1997;119:5489-5498.

29. Glasoe PK, Long FA. Use of glass electrodes to measure acidities in deuterium oxide. J. Phys. Chem 1960;64:188-189.

30. Höld KM, Sirisoma NS, Ikeda T, Narahashi T, Casida JE. $\alpha$-Thujone (the active component of absinthe): $\gamma$-aminobutyric acid type A receptor modulation and metabolic detoxication. Proc. Natl. Acad. Sci. U.S.A 2000;97:3826-3831. [PubMed: 10725394]

31. Höld KM, Sirisoma NS, Casida JE. Detoxification of $\alpha$ - and $\beta$-thujones (the active ingredients of absinthe): site specificity and species differences in cytochrome $\mathrm{P} 450$ oxidation in vitro and in vivo. Chem. Res. Toxicol 2001;14:589-595. [PubMed: 11368559]

32. De Voss JJ, Sibbesen O, Zhang Z, Ortiz de Montellano PR. Substrate docking algorithms and prediction of the substrate specificity of cytochrome P450 cam $_{\text {and }}$ its L244A mutant. J. Am. Chem. Soc 1997;119:5489-5498.

33. Rettie AE, Boberg M, Rettenmeier AW, Baillie TA. Cytochrome P450-catalyzed desaturation of valproic acid in vitro. Species differences, induction effects, and mechanistic studies. J. Biol. Chem 1988;263:13733-13738. [PubMed: 3138238]

34. Obach RS. Mechanism of cytochrome P4503A4- and 2D6-catalyzed dehydrogenation of ezlopitant as probed with isotope effects using five deuterated analogues. Drug Metab. Disp 2001;29:1599_ 1607.

35. Korzekwa KR, Trager WF, Nagata K, Parkinson A, Gillette JR. Isotope effect studies on the mechanism of the cytochrome P-450IIA1-catalyzed formation of delta 6-testosterone from testosterone. Drug Metab. Disp 1990;18:974-979.

36. Kumar D, de Visser SP, Shaik S. A predictive pattern of computed barriers for C-H hydroxylation by compound I of cytochrome P450. J. Am. Chem. Soc 2004;126:8362-8363. [PubMed: 15237977] 
37. Aikens J, Sligar SG. Kinetic solvent isotope effects during oxygen activation by cytochrome P450 cam. J. Am. Chem. Soc 1994;116:1143-1144.

38. Vidakovic M, Sligar SG, Li H, Poulos TL. Understanding the role of the essential Asp251 in cytochrome $\mathrm{P} 450_{\text {cam }}$ using site-directed mutagenesis, crystallography, and kinetic solvent isotope effect. Biochemistry 1998;37:9211-9219. [PubMed: 9649301]

39. Imai M, Shimada H, Watanabe Y, Matsushima-Hibiya Y, Makinno R, Koga H, Horiuchi T, Ishimura $\mathrm{Y}$. Uncoupling of the cytochrome $\mathrm{P} 450_{\text {cam }}$ monooxygenase reaction by a single mutation, threonine-252 to alanine or valine: possible role of the hydroxy amino acid in oxygen activation. Proc. Natl. Acad. Sci. U.S.A 1989;86:7823-7827. [PubMed: 2510153]

40. Martinis SA, Atkins WM, Stayton PS, Sligar SG. A conserved residue of cytochrome P450 is involved in heme-oxygen stability and activation. J. Am. Chem. Soc 1989;111:9252-9253.

41. Raag G, Martinis SA, Sligar SG, Poulos TL. Crystal structure of the cytochrome P450 cam active site mutant Thr252Ala. Biochemistry 1991;30:11420-11429. [PubMed: 1742281]

42. Nagano S, Poulos TL. Crystallographic study on the dioxygen complex of wild-type and mutant cytochrome $\mathrm{P} 450_{\text {cam }}$ : implications for the dioxygen activation mechanism. J. Biol. Chem 2005;280:31659-31663. [PubMed: 15994329]

43. Jin S, Makris TM, Bryson TA, Sligar SG, Dawson JH. Epoxidation of olefins by hydroperoxo-ferric cytochrome P450. J. Am. Chem. Soc 2003;125:3406-3407. [PubMed: 12643683] 


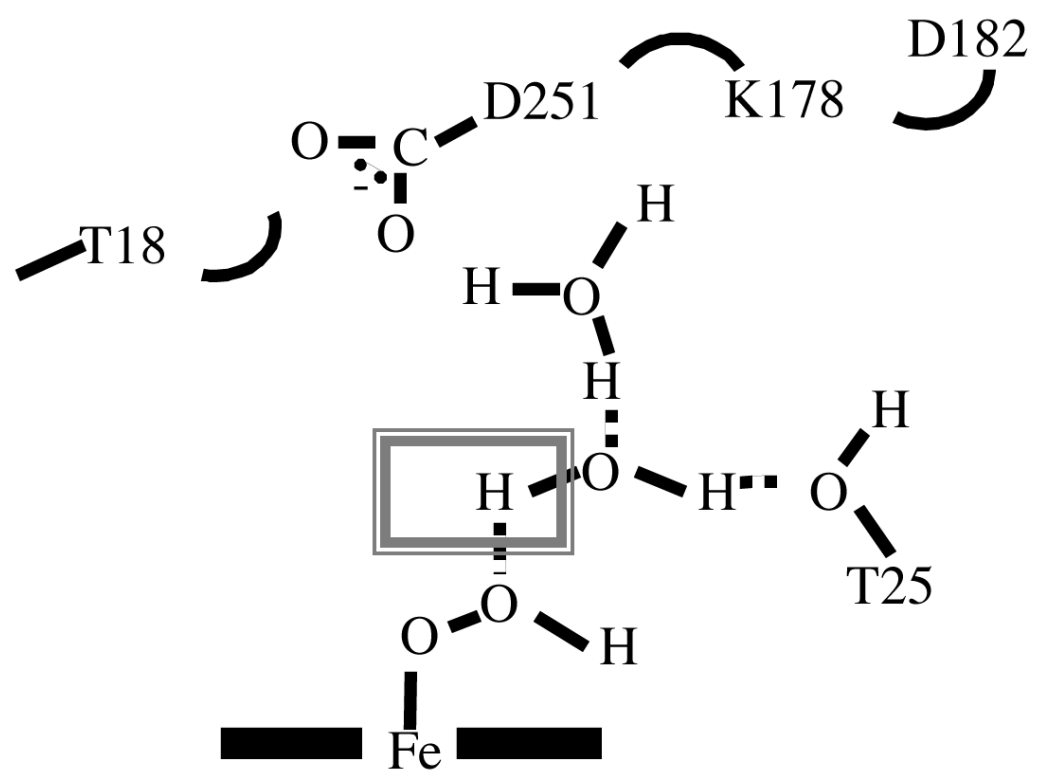

FIGURE 1.

Hydrogen bonding network proposed to be involved in conversion of the ferric hydroperoxide complex to the putative ferryl species responsible for substrate oxidation in $\mathrm{P} 450_{\text {cam }}$. This figure is based on that reported in reference (38). 

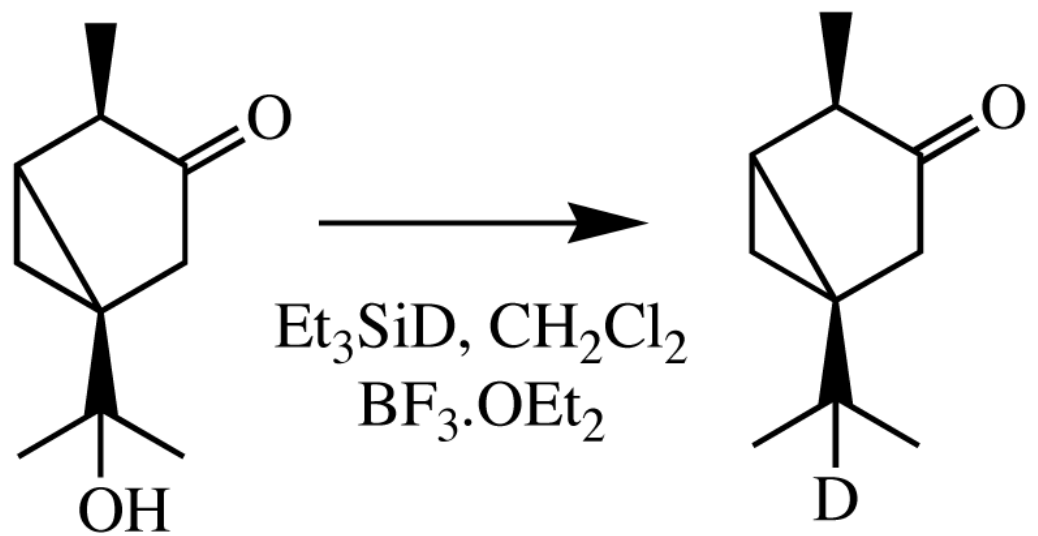

SCHEME 1.

Synthesis of $7\left[{ }^{2} \mathrm{H}\right]-\alpha$-thujone from 7-hydroxy- $\alpha$-thujone. 

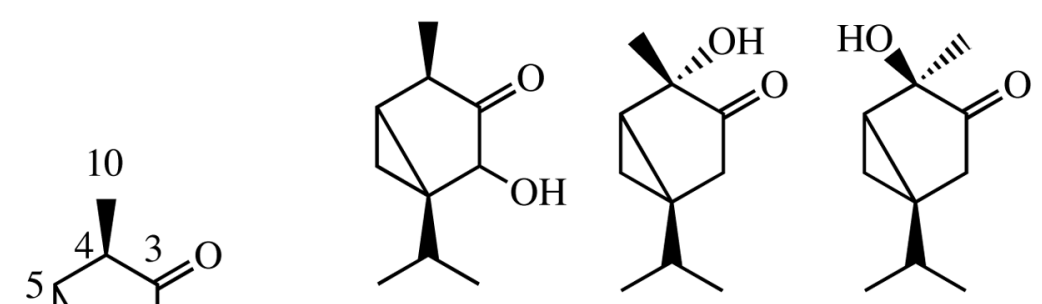<smiles>C[C@@H]1C(=O)CC2(C(C)(C)O)CC1C2</smiles>

\section{$2 \mathrm{OH} \alpha \mathrm{T}$}

$4 \mathrm{OH} \alpha \mathrm{T}$

4OH $\beta \mathrm{T} \quad 7 \mathrm{OH} \alpha \mathrm{T}$<smiles>[13CH][18OH]</smiles><smiles>C=C(C)[C@@]12CC(=O)[C@H](C)[C@H]1C2</smiles><smiles>C=C1C(=O)CC2(C(C)C)CC1C2</smiles>

$7,8 \mathrm{DH} \alpha \mathrm{T}$

4,10DHT<smiles>Cc1ccc(C(C)C)cc1O</smiles><smiles>CC1=CC[C@@H](C(C)C)CC1=O</smiles>

Carv

$\mathrm{ROP}$<smiles>CC(C)[C@@]12CC(C(=O)[C@H]1C)C2O</smiles><smiles>CC(C)[C@@]12CC(=O)[C@@](C)(O)[C@H]1C2</smiles><smiles>CC(C)[C@@]12CC(=O)[C@@](C)(O)[C@H]1C2</smiles><smiles>C[C@@H]1C(=O)CC2(C(C)(C)O)CC1C2</smiles><smiles></smiles>
$4 \mathrm{OH} \alpha \mathrm{T}$ $4 \mathrm{OH} \beta \mathrm{T} \quad 7 \mathrm{OH} \beta \mathrm{T}$<smiles>C=C(C)[C@@]12CC[C@H](CC1=O)[C@@H](C)C2</smiles><smiles>C=C1C(=O)CC2(C(C)C)CC1C2</smiles>

$7,8 \mathrm{DH} \beta \mathrm{T}$

$4,10 \mathrm{DHT}$<smiles>Cc1ccc(C(C)C)cc1O</smiles>

Carv<smiles>CC1=CC[C@@H](C(C)C)CC1=O</smiles>

ROP

SCHEME 2.

Structures of the products formed in the oxidation of $\alpha$ - and $\beta$-thujone by $\mathrm{P} 450_{\text {cam }}, \mathrm{P} 450_{\mathrm{BM}}$, and the P450 cam L244A mutant. 


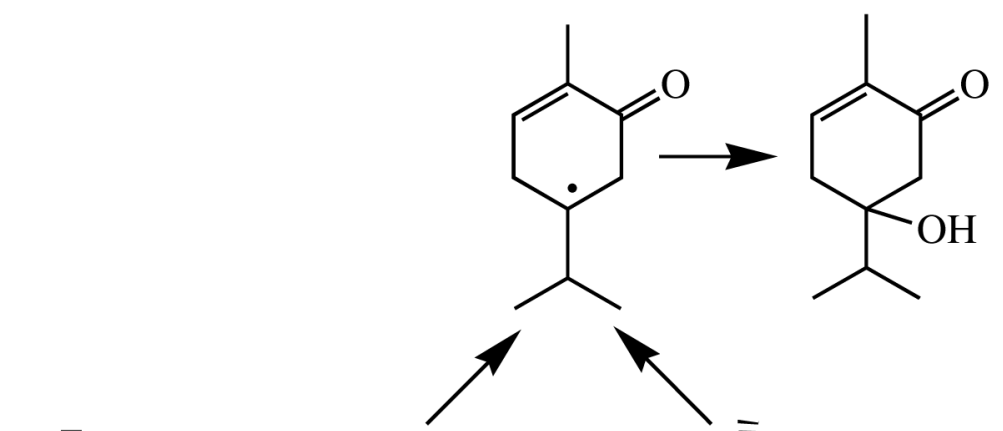<smiles>CC(C)C1[C@H]2C[C@@]1(C(C)C)CC(=O)[C@H]2C</smiles>

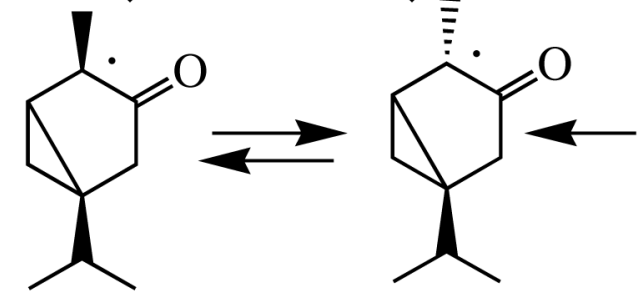<smiles>CC(C)[C@@]12CC(=O)[C@@H](C)[C@H]1C2</smiles>
$\alpha \mathrm{T}$
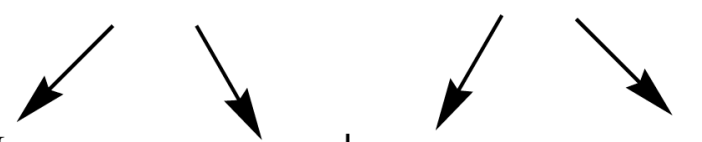

$\beta \mathrm{T}$<smiles>CC(C)[C@@]12CC(=O)[C@@](C)(O)[C@H]1C2</smiles><smiles>C=C1C(=O)C[C@]2(C(C)C)CC1C[C@@]2(C)C(C)C</smiles><smiles>CC(C)[C@@]12CC(=O)[C@@](C)(O)[C@H]1C2</smiles>

SCHEME 3.

Scheme proposed for formation of 4-hydroxy- $\alpha$-thujone, 4-hydroxy- $\beta$-thujone, 4,10 dehydrothujone, carvacrol, and the ring opened product in the P450-catalyzed oxidation of $\alpha$ and $\beta$-thujone at $\mathrm{C}-4$. 


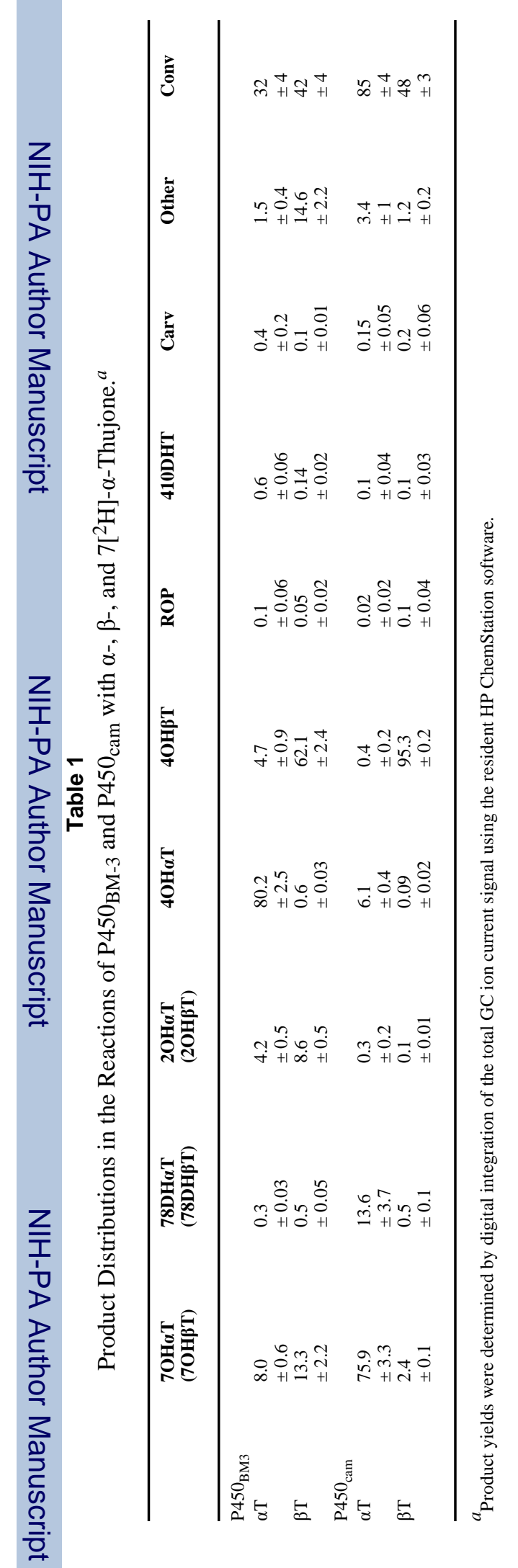


Jiang et al.

Page 21

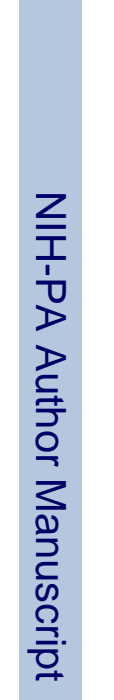

I

西

㽦 竎

颉

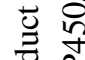

कृ

足

$\stackrel{0}{\circ} \hat{\overbrace{}}$

U ह

$.0 \frac{n}{3}$

牙

乎 号

$\stackrel{\circ}{\circ}$

월

Z U U

i

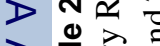

\递

容

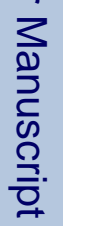

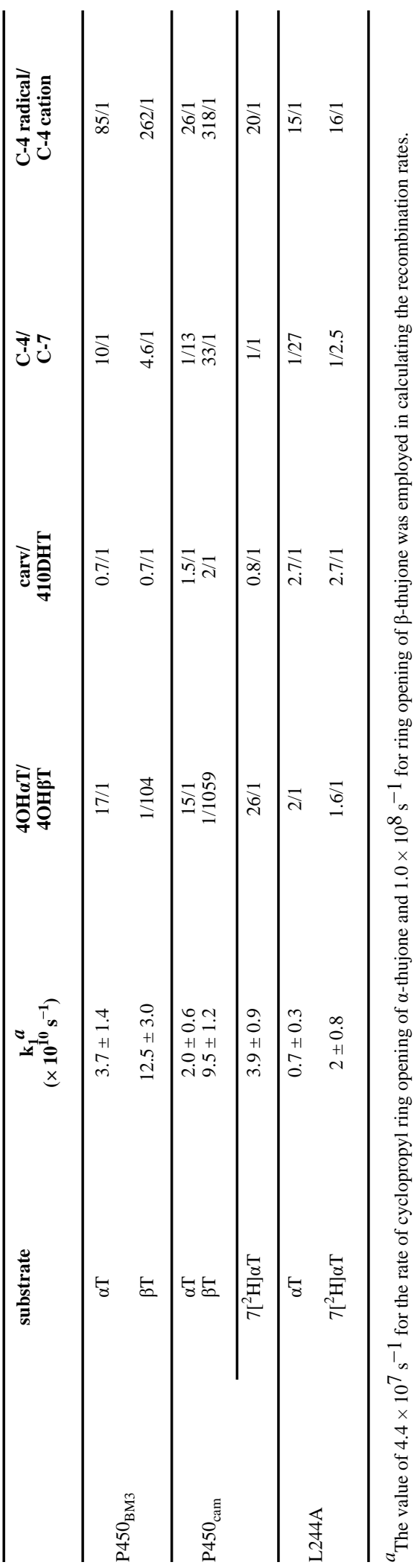

홈

Biochemistry. Author manuscript; available in PMC 2008 October 10. 


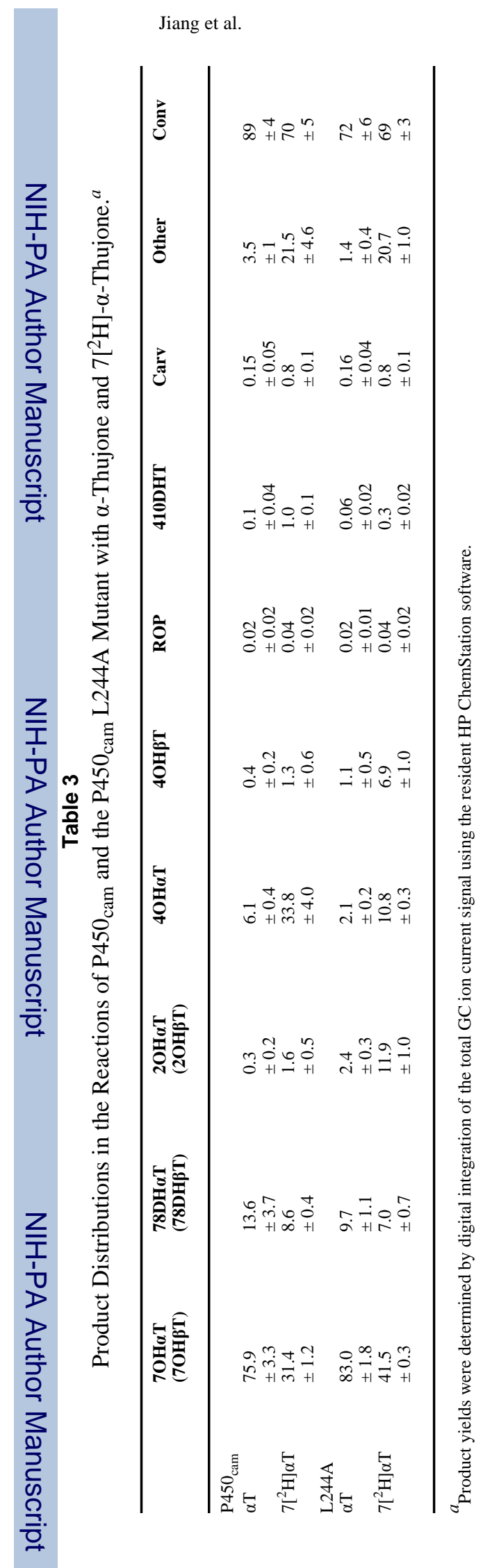

Page 22 


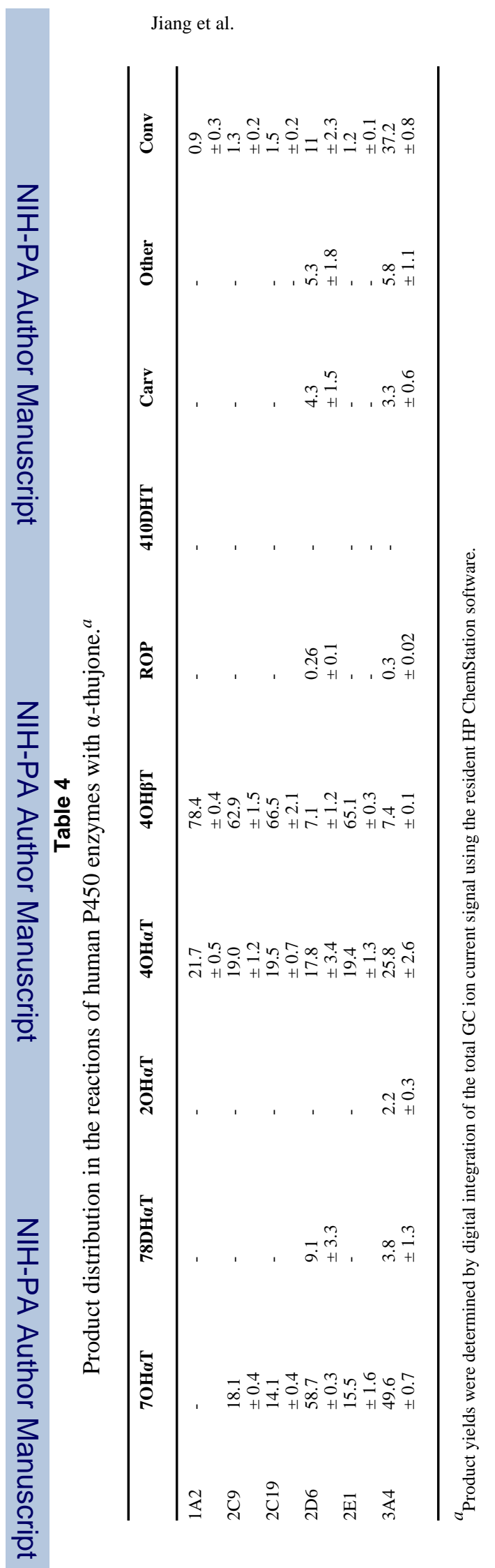

Biochemistry. Author manuscript; available in PMC 2008 October 10. 


\section{Table 5}

Radical recombination rates, C-4 methyl stereochemistry ratio, carvacrol to 4,10DHT ratio, C-4 to C-7 product ratio, and ratio of C-4 radical to cation products in the oxidation of $\alpha$-thujone by human P450 enzymes.

\begin{tabular}{|c|c|c|c|c|}
\hline & $\begin{array}{c}\mathrm{k}_{1}^{a} \\
\left(\times 10^{10} \mathrm{~s}^{-1}\right)\end{array}$ &  & $\begin{array}{l}\text { C-4/ } \\
\text { C-7 }\end{array}$ & $\begin{array}{c}\text { C-4 radical/ } \\
\text { C-4 cation }\end{array}$ \\
\hline $1 \mathrm{~A} 2$ & - & $1 / 3.6$ & - & - \\
\hline $2 \mathrm{C} 9$ & - & $1 / 3.3$ & $4.5 / 1$ & - \\
\hline $2 C 19$ & - & $1 / 3.4$ & $6.1 / 1$ & - \\
\hline 2D6 & $0.34 \pm 0.09$ & $2.5 / 1$ & $1 / 2.7$ & $16.7 / 1$ \\
\hline $2 \mathrm{E} 1$ & $\begin{array}{c}-10 \\
-10\end{array}$ & $1 / 3.4$ & $5.5 / 1$ & - \\
\hline $3 \mathrm{~A} 4$ & $0.48 \pm 0.06$ & $3.6 / 1$ & $1 / 1.3$ & $10.6 / 1$ \\
\hline
\end{tabular}

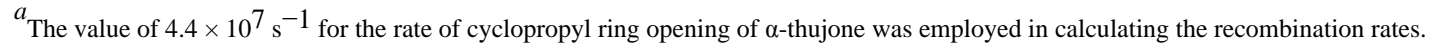

